\title{
AMPK-dependent regulation of GLP1 expression in L-like cells
}

\author{
Sushi Jiang', Hening Zhai',2, Danjie Li', Jiana Huang', Heng Zhang', Ziru Li³, \\ Weizhen Zhang ${ }^{3,4}$ and Geyang $X \mathbf{u}^{1}$ \\ 'Department of Physiology, School of Medicine, Jinan University, Guangzhou, Guangdong, China \\ 2Endoscopy Center, The First Affiliated Hospital of Jinan University, Guangzhou, Guangdong, China \\ 3Shenzhen University Diabetes Center, Shenzhen University Health Science Center, Shenzhen, Guangdong, China \\ ${ }^{4}$ Department of Surgery, University of Michigan Medical Center, Ann Arbor, Michigan, USA
}

Correspondence should be addressed to W Zhang or G Xu Email weizhenz@umich.edu or xugeyangliang@163.com

\begin{abstract}
This study examined whether AMPK, an evolutionarily conserved sensor of cellular energy status, determines the production of glucagon-like peptide-1 (GLP1).

A negative relation existed between phosphorylation of AMPK $\alpha$ and the expression and secretion of GLP1 during changes in energy status in STC-1 cells, an L-like cell line. High concentration of glucose $(25 \mathrm{mmol} / \mathrm{L})$ decreased AMPK $\alpha$ phosphorylation, whereas it stimulated the expression and secretion of GLP1 relative to $5.6 \mathrm{mmol} / \mathrm{L}$ glucose. Serum starvation upregulated AMPK $\alpha$ phosphorylation, whereas it reduced GLP1 production significantly. Stimulation of AMPK phosphorylation by AICAR and overexpression of wild-type AMPK $\alpha 1$, constitutively active AMPK $\alpha 1$ plasmids, or AMPK $\alpha 1$ lentivirus particles suppressed proglucagon mRNA and protein contents in STC-1 cells. Inactivation of AMPK by Compound C, AMPK $\alpha 1$ siRNA or kinase-inactive AMPK $\alpha 1$ mutant increased the expression and secretion of GLP1. Our results suggest that AMPK $\alpha 1$ may link energy supply with the production of GLP1 in L-like cells.
\end{abstract}

\author{
Key Words \\ - enteroendocrine L cells \\ - GLP1 \\ - energy sensing \\ - AMPK $\alpha 1$
}

\section{Introduction}

The proglucagon gene (GCG) encodes both glucagon and glucagon-like peptides (GLPs) in pancreatic $\alpha$-cells and intestinal enteroendocrine L cells as well as neurons, respectively (Baggio \& Drucker 2007). Glucagon is predominantly generated in pancreatic $\alpha$-cells by prohormone convertase (PC)-2, whereas in the gut and brain, GCG expression leads to GLP1 synthesis after cleavage by PC-1/3 (Mojsov et al. 1986, Drucker \& Asa 1988). The biologically active forms of GLP1 are GLP1(7-37) and GLP1(7-36)NH2 (Orskov et al. 1993). The half-life of bioactive GLP1 in the circulation is less than 2 min owing to rapid inactivation by the ubiquitous proteolytic enzyme dipeptidyl peptidase-4 (DPP4) (Deacon et al. 1995).
DPP4 rapidly converts GLP1(7-37) and GLP1(7-36) NH2 to their inactive metabolites GLP1(9-37) or GLP1(9-36)NH2 (Hansen et al. 1999). GLP1 secretion occurs primarily in response to nutrient ingestion, through a complex array of direct and indirect mechanisms (Baggio \& Drucker 2007). Postprandial GLP1 levels peak within 15-30 min of nutrient consumption. GLP1, a potent antihyperglycemic hormone, induces glucose-dependent stimulation of insulin secretion, whereas suppresses glucagon secretion (Herrmann et al. 1995). Such glucose-dependent action is attractive particularly because when the plasma glucose concentration is in the normal fasting range, GLP1 no longer stimulates insulin release, thus avoiding 
hypoglycemia (Elahi et al. 1994). Insulinotropic activity of GLP1 in type 2 diabetes mellitus, therefore, offers great potential for treatment of hyperglycemia without causing hypoglycemia (Elahi et al. 1994). Current GLP1-based therapies include long-acting GLP1 receptor (GLP1R) agonists (Buse et al. 2004) and inhibitors of GLP1 degradation (Aschner et al. 2006). With the introduction of GLP1-based treatments into the clinical practice, interest in factors that regulate the release of endogenous GLP1 has been heightened.

AMPK, which consists of a catalytic $\alpha$-subunit and noncatalytic $\beta$ - and $\gamma$-subunits, is a fuel sensor and regulator that plays a vital role in cellular energy homeostasis (Kim \& Lee 2005). Enzyme activity is regulated both allosterically by AMP and by reversible phosphorylation at Thr-172 of the $\alpha$-subunit by an upstream kinase (AMPK kinase or AMPKK) (Hardie et al. 1999). AMPK controls whole-body glucose homeostasis by regulating metabolism in multiple peripheral tissues such as skeletal muscle, liver, adipose tissues and pancreatic $\beta$-cells (De Morentin et al. 2011). By responding to diverse nutritional and hormonal signals, AMPK serves as an integrator of intertissue signals among peripheral tissues and the hypothalamus to control energy intake and whole-body energy balance (Minokoshi et al. 2004, De Morentin et al. 2011). The effects of AMPK on GLP1 synthesis in L cells remain largely uncharacterized.

Our previous studies demonstrate that mTORC1 enhances GLP1 synthesis (Xu et al. 2015a,b). As AMPK has been characterized to suppress mTOR signaling (Inoki et al. 2006), we hypothesize that AMPK contributes to the regulation of GLP1 production. Here, we present evidence that AMPK $\alpha 1$ regulates the production of GLP1 in STC-1 cells. Our data identify AMPK as a critical mechanism regulating proglucagon gene expression and GLP1 secretion, thus expanding its interest as a potential target for the treatment of type 2 diabetes mellitus.

\section{Materials and methods}

\section{Materials}

Diprotin was from Sigma Chemical. Control lentiviral activation particles, AMPK $\alpha 1$ lentiviral activation particles, Polybrene, control siRNA, AMPK $\alpha 1$ siRNA and mouse anti-AMPK $\alpha 1$ antibody were purchased from Santa Cruz Inc (Santa Cruz, USA). AICAR, mouse anti$\beta$-actin, rabbit anti-AMPK $\alpha$ (Thr172) and rabbit antiAMPK $\alpha$ antibodies were obtained from Cell Signaling Technology. Rabbit anti-AMPK $\alpha 2$ antibody and mouse
anti-GLP1 were from Abcam. IRDye-conjugated affinitypurified anti-rabbit, anti-mouse IgGs were purchased from Rockland (Gilbertsville, PA, USA). TRIzol reagent and the reverse transcription (RT) system were from Promega. Lipofectamine was purchased from Invitrogen. Compound C and Glucagon-Like Peptide- 1 Active enzyme immunoassay kit were purchased from Millipore.

\section{Cell culture and transfection}

The intestinal secretin tumor cell line (STC-1) was purchased from ATCC. All experiments were performed using passages 20-25. STC-1 cells were maintained in DMEM medium supplemented with $2.5 \%$ fetal bovine serum and $10 \%$ horse serum at $37^{\circ} \mathrm{C}$ in an atmosphere of $5 \% \mathrm{CO}_{2}$ air. For transient transfection, cells were plated at optimal densities and grown for $24 \mathrm{~h}$. Cells were then transfected with the following constructs: GFP, wild-type AMPK $\alpha 1$ (WT), constitutively active form of AMPK $\alpha 1$ (AF), or the dominant negative form of AMPK $\alpha 1$ (DN) plasmids (Corradetti et al. 2004, Inoki et al. 2006) using Lipofectamine reagent according to the manufacturer's instruction.

\section{Infection of AMPK $\alpha 1$ lentivirus}

Lentiviral infection was performed according to the manufacturer's instruction. The infected STC-1 cells were seeded in a 6-well tissue culture plate and grown to about $80 \%$ confluency. A mixture of complete medium with Polybrene at a final concentration of $5 \mu \mathrm{g} / \mathrm{mL}$ was prepared, and $3 \mathrm{~mL}$ of the mixture were added to each

Table 1 Anthropometric data (ESM).

\begin{tabular}{|c|c|c|c|}
\hline Parameter & Lean & Obese & $P$ value \\
\hline Age (years) & $52 \pm 3.5$ & $43 \pm 12.7$ & 0.545 \\
\hline Body weight (kg) & $59 \pm 2.2$ & $99 \pm 14.3^{*}$ & 0.04 \\
\hline BMI $\left(\mathrm{kg} / \mathrm{m}^{2}\right)$ & $23.3 \pm 2.2$ & $41.2 \pm 7.8^{*}$ & 0.012 \\
\hline $\begin{array}{l}\text { Fasting plasma glucose } \\
(\mathrm{mmol} / \mathrm{L})\end{array}$ & $5 \pm 0.2$ & $8 \pm 0.3 *$ & 0.023 \\
\hline HbAlc $(\%)$ & $3.9 \pm 0.3$ & $7.6 \pm 0.5^{*}$ & 0.013 \\
\hline Total cholesterol (mmol/L) & $5.9 \pm 1.3$ & $4.6 \pm 0.3$ & 0.4169 \\
\hline Triacylglycerol (mmol/L) & $1.4 \pm 0.3$ & $2.6 \pm 0.4^{*}$ & 0.036 \\
\hline Aspartate transaminase (U/L) & $18.3 \pm 2.9$ & $26.3 \pm 2.4$ & 0.1 \\
\hline Alanine transaminase (U/L) & $18.3 \pm 5.8$ & $35.3 \pm 2.9 *$ & 0.043 \\
\hline
\end{tabular}

Anthropometric data. All patients undertook a 12-h fasting before blood collection for biochemical tests. Fasting was either self-administered or managed during the hospital stay. Clinical biochemistry testing was conducted by Hitachi Automatic Biochemistry Analyzer (Hitachi High-technologies Corporation, Tokyo). HbA1c was analyzed by high-performance liquid chromatography (Bio-Rad-D10). All values are expressed as mean \pm S.E.M, $n=3, * P<0.05$ vs lean participants.

Published by Bioscientifica Ltd 
well of cultured cells. Lentiviral activation particles were thawed at room temperature and mixed gently before use. AMPK $\alpha 1$ lentiviral activation particles or control lentiviral activation particles were administrated to cultured STC-1 cells. Culture plates were swirled gently to mix the lentivirus. Then, the cells were incubated for $48 \mathrm{~h}$.

\section{Recruitment of human subjects and collection of colon mucosa}

Three obese male participants with type 2 diabetes and 3 age-matched lean normal glycemic male participants were enrolled in the study. Anthropometric data are provided in Table 1 (ESM). Participation in this study was voluntary, and written informed consent was obtained from each participant. The guidelines of the Declaration of Helsinki (2000) of the World Medical Association were followed. All protocols were approved by the Research Ethics Committee of The First Affiliated Hospital of Jinan University.

All participants were fasted for $8 \mathrm{~h}$. An enteroscopy was performed in sedated participants using a colonoscope (CF-HQ290I; Olympus). Mucosal biopsies were taken from colon. Tissue samples were extracted for protein and RNA using lysis buffer and RNA TRIzol, respectively.

\section{Western blot analysis}

Colon mucosa and culture cells were quickly harvested, rinsed thoroughly with PBS and then homogenized on ice in the protein lysis buffer $(50 \mathrm{mmol} / \mathrm{L}$ Tris-HCl; $15 \mathrm{mmol} / \mathrm{l} \mathrm{EGTA;} 100 \mathrm{mmol} / \mathrm{L} \mathrm{NaCl} ; 0.1 \%$ Triton X-100 supplemented with protease inhibitor cocktail, $\mathrm{pH} 7.5$ ). After centrifugation for $10 \mathrm{~min}$ at $4^{\circ} \mathrm{C}$, the supernatant was used for Western blot analysis. Protein concentration was measured by Bradford's method. Proteins were loaded onto SDS-PAGE gels and then transferred to nitrocellulose membranes. The membranes were incubated for $1 \mathrm{~h}$ at room temperature with $5 \%$ fat-free milk in Tris-buffered saline containing Tween 20, followed by incubation overnight at $4^{\circ} \mathrm{C}$ with the primary antibodies. Specific reaction was detected using IRDye-conjugated second antibody and visualized using the Odyssey Infrared Imaging System (LI-COR Biosciences, Lincoln, NE, USA).

\section{RNA extraction and quantitative real-time PCR analysis}

For gene expression analysis, RNA was isolated from colon mucosa and STC-1 cells using TRIzol (Invitrogen) and reverse transcribed into cDNAs using the FirstStrand Synthesis System for RT-PCR kit (Invitrogen).
SYBR Green-based quantitative RT-PCR was performed using the Mx3000 multiplex quantitative PCR system (Stratagene). Triplicate samples were collected for each experimental condition to determine relative expression levels. Sequences for the primer pairs used in this study are as follows: mouse proglucagon (accession no. NM_008100.3), sense 5'-ATT GCC AAA CGT CAT GAT GA-3' and antisense 5'-GGC GAC TTC TTC TGG GAA GT-3'; mouse $\beta$-actin (accession no. NM 007393.3), sense 5'-ATC TGG CAC CAC ACC TTC-3' and antisense 5'-AGC CAG GTC CAG ACG CA-3'; human proglucagon (accession no. NM_002054.4), sense 5'-GCA CAT TCA CCA GTG ACT ACA GCA-3' and antisense 5'-TGG CAG CTT GGC CTT CCA AAT A-3'; human TFIIB (accession no. NM_001514.5), sense 5'-ACC AGC CGT TTG GAT GCT C-3' and antisense 5'-CCC ACA TCA ATA ACC CGG TC-3'.

\section{Measurements of GLP1}

Measurements of GLP1 secretion were performed as described previously ( $\mathrm{Xu}$ et al., 2015b). Samples were collected in the presence of aprotinin $(2 \mu \mathrm{g} / \mathrm{mL})$, EDTA $(1 \mathrm{mg} / \mathrm{mL})$ and Diprotin $(0.1 \mathrm{mmol} / \mathrm{L})$. Cell culture medium was harvested and stored at $-80^{\circ} \mathrm{C}$ before use. Glucagon-like peptide-1 (active forms) was assayed using the enzyme immunoassay kit according to the manufacturer's instruction, which is highly specific for the immunologic measurement of active GLP1(7-36 amide) and GLP1(7-37) in plasma and will not detect other forms of GLP1 (e.g., 1-36 amide, 1-37, 9-36 amide or 9-37).

\section{Statistical analysis}

All data were expressed as mean \pm s.E.M. Statistical significance was analyzed with an unpaired Student's $t$-test. Data were considered significant when $P<0.05$.

\section{Results}

Effects of glucose and serum deprivation on the phosphorylation of AMPK $\alpha$ and expression of GLP1 in STC-1 cells

As shown in Fig. 1A, phosphorylation of endogenous AMPKa on Thr172 in STC-1 cells was decreased by high glucose relative to low glucose. This change was associated with an increase in GLP1 synthesis and secretion. mRNA (Fig. 1B) and protein levels (Fig. 1A) of proglucagon and GLP1 secretion

Published by Bioscientifica Ltd 
(Fig. 1C) were significantly higher when STC-1 cells were cultured at $25 \mathrm{mmol} / \mathrm{L}$ glucose than at $5.6 \mathrm{mmol} / \mathrm{L}$ glucose.

The effects of serum deprivation on AMPK $\alpha$ phosphorylation and GLP1 production were next examined. Serum starvation significantly inhibited the proglucagon mRNA and protein, as well as GLP1 secretion, but stimulated AMPK $\alpha$ phosphorylation (Fig. 1D-F).

These in vitro experiments indicate that negative energy balance upregulates $\mathrm{AMPK} \alpha$ phosphorylation, which subsequently inhibits GLP1 production in L-like cells. We then examined the effects of long-term changes in nutritional status on $\mathrm{AMPK} \alpha$ phosphorylation and GLP1 production in colon mucosa of human subjects. As shown in Fig. 2A, levels of phosphorylated AMPK $\alpha$ in colon mucosa were significantly decreased in obese patients with $41.2 \pm 7.8 \mathrm{~kg} / \mathrm{m}^{2}$ body mass index (BMI) relative to lean human subjects (BMI $23.3 \pm 2.2 \mathrm{~kg} / \mathrm{m}^{2}$ ). In contrast to the changes in $\mathrm{AMPK} \alpha$, proglucagon mRNA (Fig. 2B) and protein (Fig. 2A) demonstrated a significant increase in obese subjects compared with lean people.
A

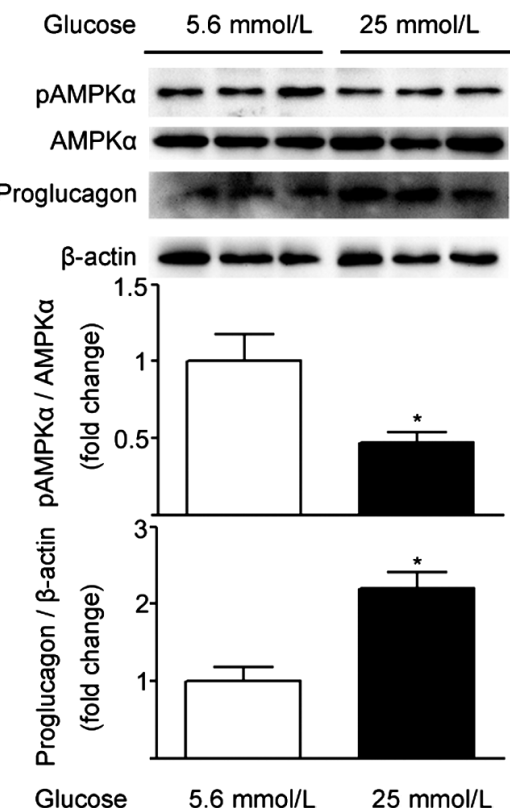

D

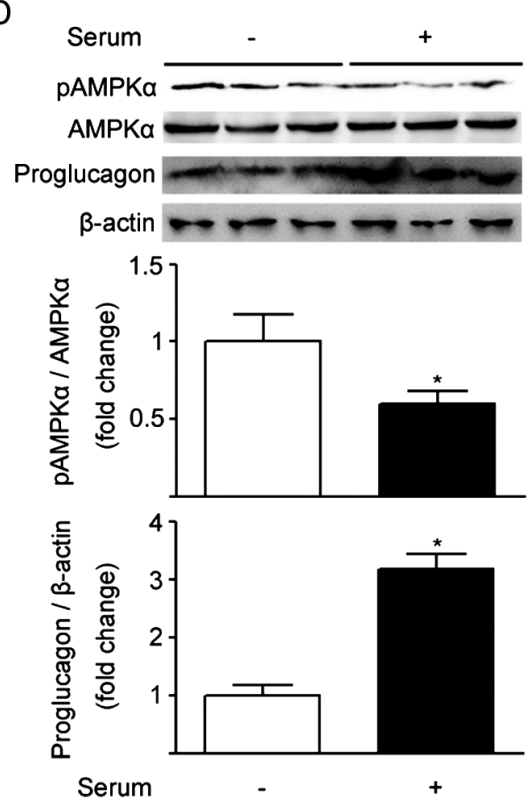

B

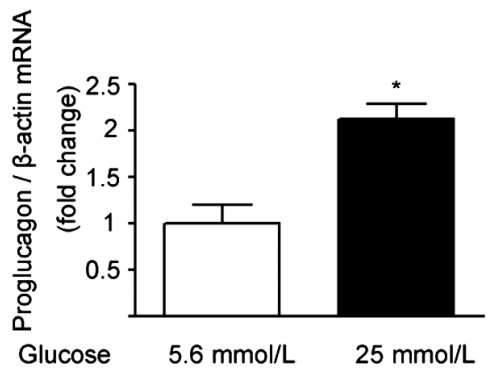

C

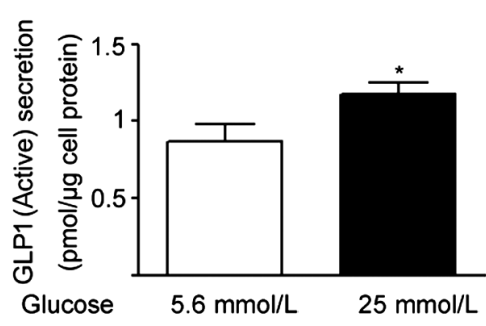

E

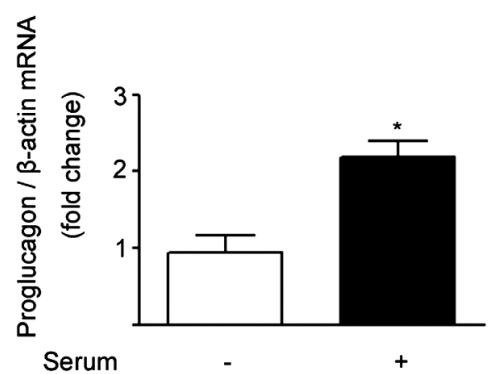

$\mathrm{F}$

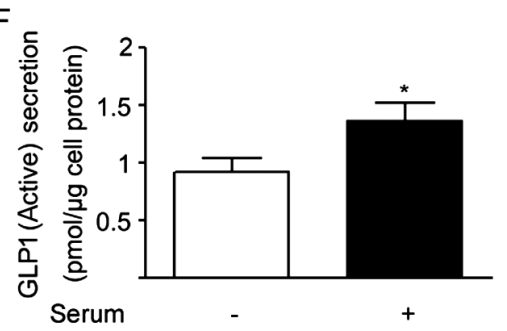

Figure 1

Effects of glucose and serum deprivation on the phosphorylation of AMPK $\alpha$ and expression of GLP1 in STC-1 cells. Cultured STC-1 cells were incubated for $24 \mathrm{~h}$ in the presence of $5.6 \mathrm{mmol} / \mathrm{L}$ (low) or $25 \mathrm{mmol} / \mathrm{L}$ (high) glucose supplemented with $2.5 \%$ fetal bovine serum and $10 \%$ horse serum (A-C). STC-1 cells were maintained in high glucose DMEM medium supplemented with indicated serum or serum deprivation for $24 \mathrm{~h}$ (D-F). Shown are representative Western blots for phospho-AMPK $\alpha$ (pAMPK $\alpha$, Thr172) and proglucagon. AMPK $\alpha$ and $\beta$-actin were used as loading controls ( $A$ and $D$ ). Proglucagon mRNA ( $B$ and $E$ ) was analyzed by quantitative PCR, normalized to $\beta$-actin and expressed as fold change from control. Medium GLP1 ( $C$ and F) was determined by enzyme immunoassay. Results are expressed as mean \pm s.E.M.

Experiments were repeated for three times. *Denotes $P<0.05$ vs control. 


\section{Inhibition of GLP1 synthesis and secretion by AMPK $\alpha 1$ in STC-1 cells}

The direct effects of AICAR, an activator of AMPK, on GLP1 synthesis and secretion were next examined in cultured STC-1 cells. Exposure of STC-1 cells to AICAR at the doses ranging from 31.25 to $250 \mu \mathrm{mol} / \mathrm{L}$ for $24 \mathrm{~h}$ caused a concentration-dependent increase in AMPK $\alpha$ phosphorylation (Fig. 3A) and a decrease in proglucagon mRNA (Fig. 3B) and protein (Fig. 3A) and medium content of GLP1 (Fig. 3C).

A
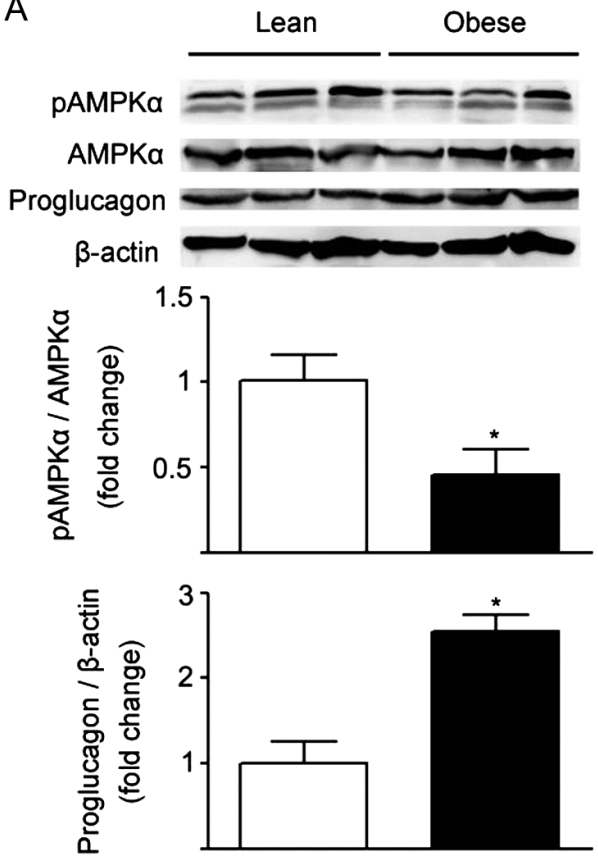

B

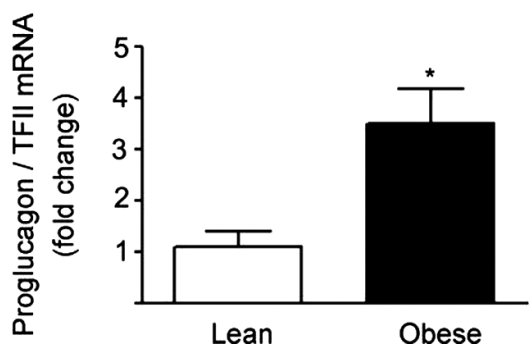

Figure 2

Downregulation of colonic AMPK $\alpha$ and upregulation of GLP1 production in obese human subjects. (A) Representative Western blot from colon mucosa of lean and obese human subjects. Phospho-AMPK $\alpha$ (pAMPK $\alpha$, Thr172) and proglucagon were blotted as described in 'Materials and methods' section. AMPK $\alpha$ and $\beta$-actin were used as loading controls. Quantification of image analysis of colonic AMPK $\alpha$ phosphorylation and proglucagon expression is expressed as mean \pm S.E.M. (B) Results of quantitative PCR analysis of proglucagon mRNA are expressed as fold increase from lean subjects using TFII as loading control. Three colonic samples were examined for each condition. ${ }^{*} P<0.05$ vs lean subjects.
Consistent with the pharmacological AMPK, overexpression of wild-type AMPK $\alpha 1$ (WT) or constitutively active AMPK $\alpha 1$ (AF) plasmids significantly inhibited the proglucagon mRNA and protein, as well as GLP1 secretion in cultured STC-1 cells (Fig. 4A-C). On the other hand, there is no significant change in GLP1 production in STC-1 cells overexpressing AMPK $\alpha 2$ plasmids (Supplementary Fig. 1, see section on supplementary data given at the end of this article). Overexpression of constitutively active AMPK $\alpha 1$ upregulated the expression and phosphorylation of AMPK $\alpha 1$ (Fig. 4A). Further, overexpression of AMPK $\alpha 1$ lentivirus in cultured STC-1 cells significantly enhanced the phosphorylation and expression of AMPK $\alpha 1$ (Fig. 4D). The increment of AMPK $\alpha 1$ was associated with a decrease of proglucagon mRNA and protein levels (Fig. 4E and D), as well as GLP1 secretion (Fig. 4F).

\section{Stimulation of GLP1 synthesis and secretion by inhibition of AMPK $\alpha 1$ in STC-1 cells}

The direct effects of selective and reversible inhibition of AMPK on GLP1 synthesis and secretion were next examined by treating cultured STC-1 cells with Compound C. As shown in Fig. 5A-C, Compound C, at a dose ranging from 1.25 to $20 \mu \mathrm{mol} / \mathrm{L}$, induced a concentration-dependent increase in GLP1 synthesis and secretion. Compound C caused a concentrationdependent inhibition in AMPK $\alpha$ phosphorylation, which was associated with an increment in proglucagon mRNA and protein levels, as well as GLP1 release (Fig. 5A-C). Further, Compound $\mathrm{C}$ pretreatment abolished the AICARinduced reduction in GLP1 synthesis and secretion, and enhancement of AMPK $\alpha$ phosphorylation (Fig. 5D-F).

Transfection of a kinase-inactive AMPK mutant (AMPK $\alpha 1-D N$ ) plasmid caused a marked the GLP1 synthesis and secretion (Fig. 4A-C). Levels of phosphoAMPK $\alpha 1$ were significantly decreased in cells transfected with AMPK $\alpha 1-D N$.

On the other hand, siRNA knockdown of endogenous AMPK $\alpha 1$ significantly increased proglucagon mRNA and protein levels (Fig. $6 \mathrm{~A}$ and B), as well as GLP1 secretion (Fig. 6C) in cultured STC-1 cells. Knockdown of AMPK $\alpha 1$ markedly inhibited the phosphorylation and expression of AMPK $\alpha 1$ (Fig. 6A).

\section{Discussion}

The major finding of this study is that AMPK in STC-1 cells functions to alter the expression and secretion of GLP1. This conclusion is supported by the following distinct

Published by Bioscientifica Ltd 
A

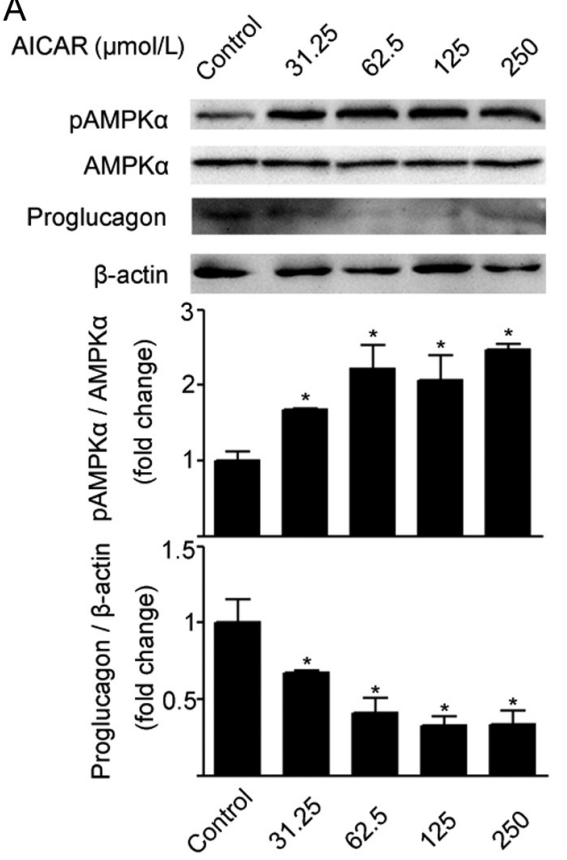

B

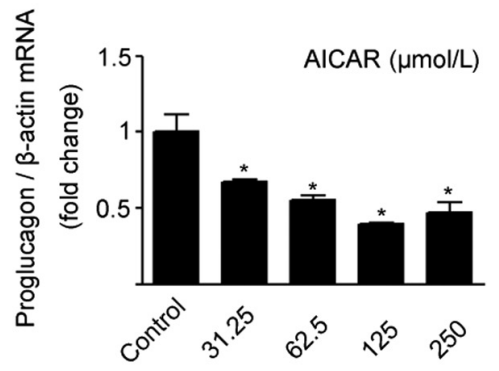

C

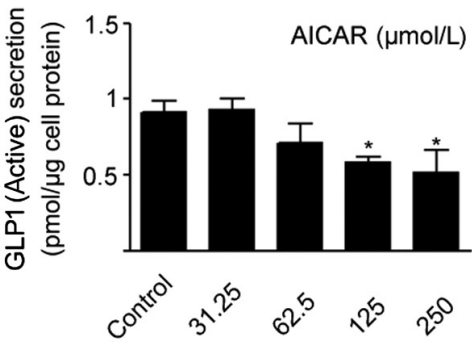

Figure 3

Suppression of GLP1 synthesis and secretion by AICAR in STC-1 cells. Cultured STC-1 cells were treated with different concentrations of AICAR for $24 \mathrm{~h}$. Proglucagon mRNA (B) and protein (A) were analyzed by RT-PCR and Western blotting. Medium GLP1 (C) was determined by enzyme immunoassay. Results are expressed as mean \pm S.E.M. Experiments were repeated for three times. ${ }^{*} P<0.05$ vs control. observations: (1) there exists a negative relation between AMPK $\alpha$ phosphorylation and the production of GLP1 in response to negative energy supply such as glucose deficiency and serum deprivation in cultured STC-1 cells or positive energy balance in obese human subjects; (2) stimulation of $\mathrm{AMPK} \alpha 1$ by either pharmacological or genetic approaches suppresses proglucagon mRNA and protein content in STC-1 cells; and (3) conversely, inhibition of $A M P K \alpha 1$ signaling by Compound $C$, AMPK $\alpha 1$ siRNA or a dominant negative form of AMPK $\alpha 1$ increases the expression and secretion of GLP1.

Enteroendocrine L cells are mainly expressed in the distal ileum and colon. In response to nutrients such as glucose and monounsaturated fatty acids, these
A

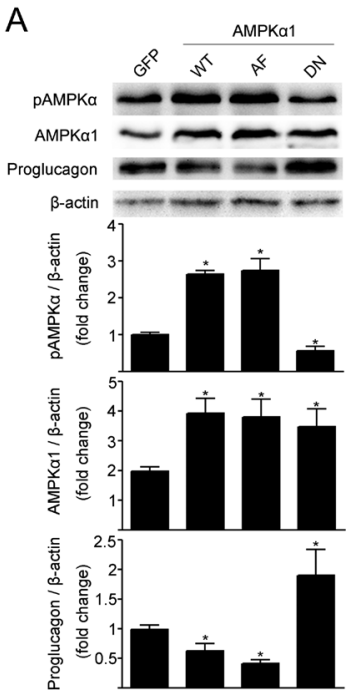

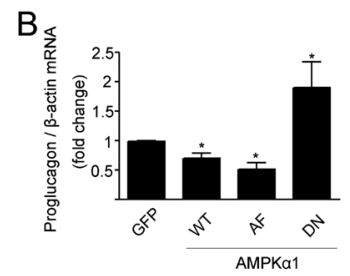

C

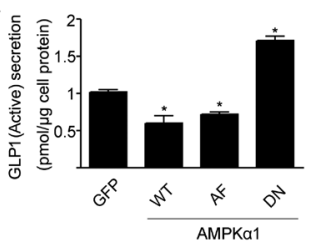

D

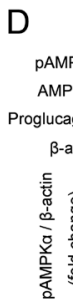

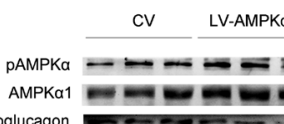

Proglucagon $=-2-2=$

B-actin

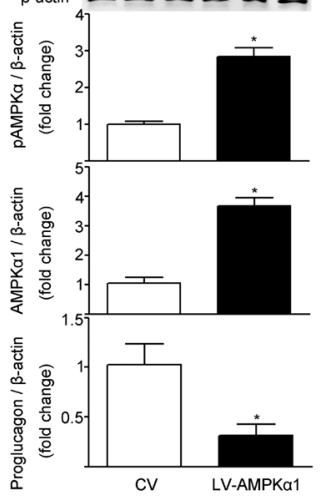

E

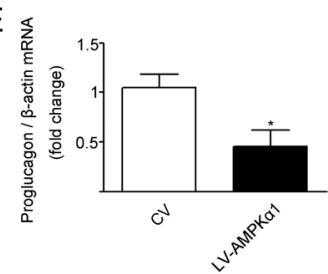

$\mathrm{F}$

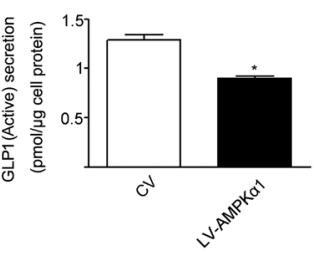

Figure 4

Regulation of GLP1 production by overexpression of AMPK $\alpha 1$ gene in STC-1 cells. Effects of AMPK $\alpha 1$ plasmids (A-C). STC-1 cells were transfected for $48 \mathrm{~h}$ with GFP, wild-type AMPK $\alpha 1$ (WT), constitutively active form of AMPK $\alpha 1$ (AF) or a dominant negative form of AMPK $\alpha 1$ (DN) plasmids using Lipofectamine. Phospho-AMPK $\alpha$, proglucagon, AMPK $\alpha 1$ and $\beta$-actin (A), proglucagon mRNA (B), and medium GLP1 (Active) concentration (C) were measured and expressed as mean \pm S.E.M. $n=3 ;{ }^{*} P<0.05$ vs control. Effects of AMPK $\alpha 1$ lentivirus (D-F). STC- 1 cells were infected with control lentivirus (CV) or lentiviral particles coding for AMPK $\alpha 1$ (LV-AMPK $\alpha 1$ ) for $48 \mathrm{~h}$. (D) Representative Western blots of phospho-AMPK $\alpha$, proglucagon, AMPK $\alpha 1$ and $\beta$-actin. (E) Proglucagon mRNA. (F) Medium GLP1 (Active) concentration. Results were expressed as mean \pm s.E.M. $n=3$; $* P<0.05$ vs control.

http://jme.endocrinology-journals.org DOI: 10.1530/JME-16-0099
C 2016 Society for Endocrinology Printed in Great Britain
Published by Bioscientifica Ltd 
A

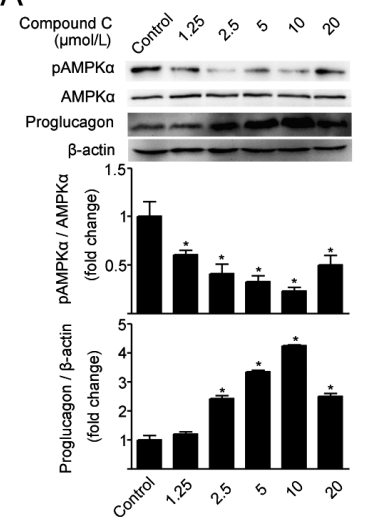

B
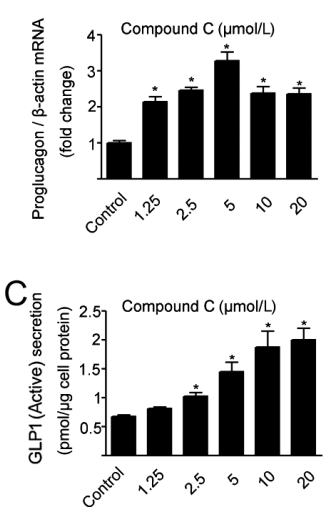

Figure 5

Stimulation of GLP1 synthesis and secretion by Compound C in STC-1 cells. (A-C) Cultured STC-1 cells were treated with varying concentrations of Compound $\mathrm{C}$ for $24 \mathrm{~h}$. Phospho-AMPK $\alpha$, AMPK $\alpha$ and proglucagon protein were analyzed by Western blotting (A). Results of quantitative PCR analysis of proglucagon mRNA are expressed as fold increase from vehicle control using $\beta$-actin as loading control (B). Medium GLP1 (C) was determined by enzyme immunoassay. Results are expressed as mean \pm S.E.M. Experiments were repeated for three times. ${ }^{*} P<0.05$ vs control. (D-E) Cultured STC- 1 cells were treated with DMSO, AICAR $(125 \mu \mathrm{M})$, Compound C $(10 \mu \mathrm{M})$ or AICAR plus Compound C for $24 \mathrm{~h}$. Phospho-AMPK $\alpha$, AMPK $\alpha$ and proglucagon protein (D) were analyzed by Western blotting. Proglucagon mRNA (E) was analyzed by RT-PCR. Medium GLP1 (F) was determined by enzyme immunoassay. Results are expressed as mean \pm S.E.M. Experiments were repeated for 3 times. ${ }^{*} P<0.05$ vs control.

cells secrete GLP1 (Mansour et al. 2013). The molecular mechanism by which L cells sense nutrients to and then alter the secretion of GLP1 remains largely unknown. Adenosine 5'-monophosphate (AMP)-activated protein kinase (AMPK), mammalian target of rapamycin (mTOR) and peroxisome proliferator-activated receptors (PPARs) have been reported to serve as crucial cellular energy sensors to regulate cell metabolism (Jiang et al. 2015).
A

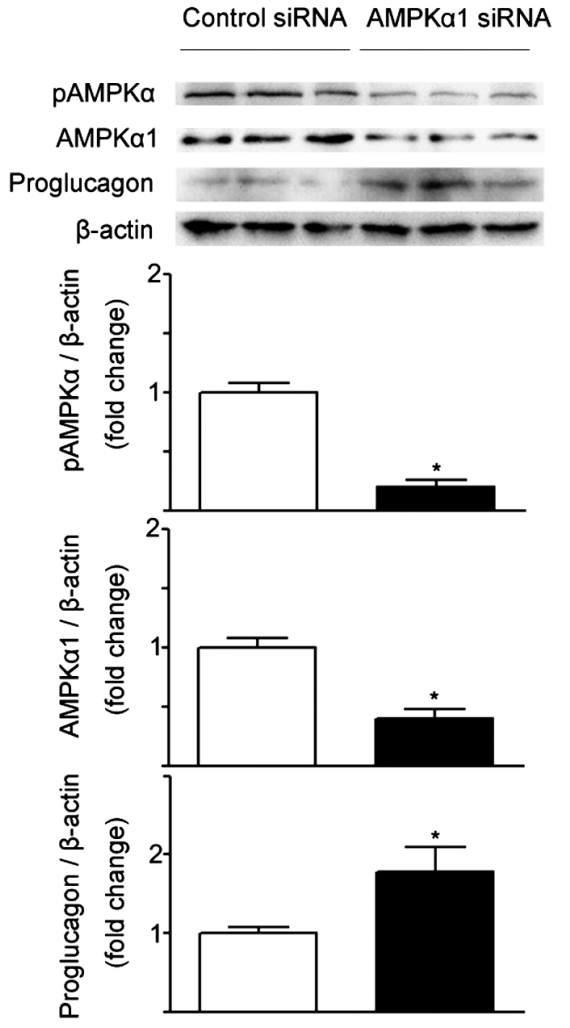

B

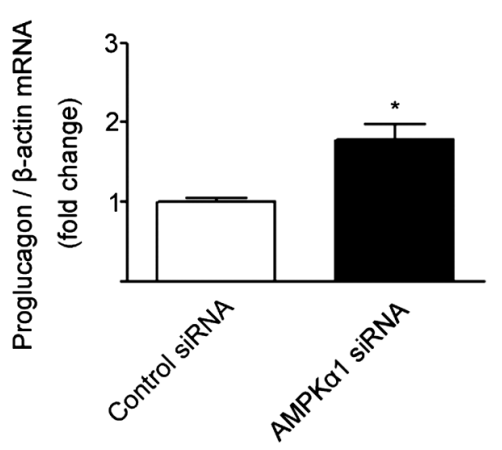

C

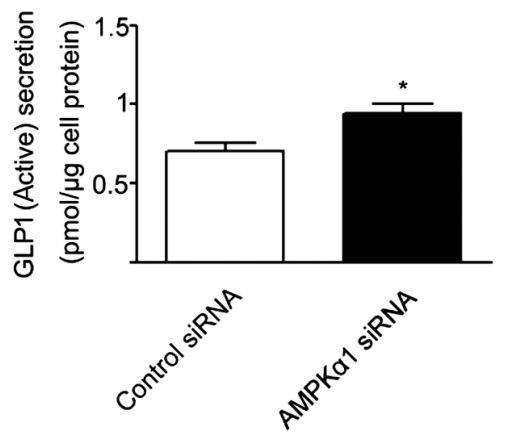

Figure 6

Effects of AMPK $\alpha 1$ gene manipulation on GLP1 production. STC-1 cells were transfected with control siRNA or AMPK $\alpha 1$ siRNA for $48 \mathrm{~h}$. (A) Representative Western blots of phosphoAMPK $\alpha$, proglucagon, AMPK $\alpha 1$ and $\beta$-actin. (B) Proglucagon mRNA. (C) Medium GLP1 (Active) concentration. Results were expressed as mean \pm s.E.M. $n=3 ; * P<0.05$ vs control. http://jme.endocrinology-journals.org DOI: 10.1530/JME-16-0099
๑) 2016 Society for Endocrinology Printed in Great Britain 
We thus speculate that GLP1 biosynthesis and secretion can be modulated by these nutrient-sensing molecules. Our previous report has demonstrated that mTORC1 may function to integrate nutritional and hormonal signals such as ghrelin with the synthesis and secretion of GLP1 within L cells (Xu et al. 2015a,b). This study extends the nutrient-sensing mechanism in L cells to AMPK signaling. Our finding demonstrates that AMPK $\alpha 1$ is altered by cellular energy status in STC-1 cells, an L-like cell line, and in colon mucosa of human subjects. Phosphorylation of AMPK $\alpha 1$ increases during negative energy balance such as glucose deficiency or serum deprivation, whereas its level decreases during long-term energy surplus in obese human subjects. These observations are consistent with other studies demonstrating that AMPK is critical for nutrient and hormone sensing in a variety of cells ranging from central nervous system to peripheral tissues (Kim \& Lee 2005). In hypothalamic neurons, AMPK integrates nutritional signals with feeding behavior (Minokoshi et al. 2004, De Morentin et al. 2011, Stark et al. 2013). In muscle and liver, AMPK improves insulin sensitivity (Friedrichsen et al. 2013, Hasenour et al. 2013). In pancreatic islets, AMPK links the extracellular glucose with transcription of preproinsulin and secretion of insulin (Da Silva Xavier et al. 2000, 2003). Using pharmacological and genetic intervention for gain or loss of function of AMPK $\alpha 1$, we demonstrate that AMPK $\alpha 1$ negatively regulates production and secretion of GLP1 in L cells. By simultaneously inducing glucose-dependent stimulation of insulin secretion and suppressing glucagon secretion, GLP1 functions as a potent antihyperglycemic hormone (Baggio \& Drucker 2007). Modulation of GLP1 synthesis and secretion by AMPK in L cells may thus coordinate the level of glucose in an organism with secretion of insulin, leading to the fine control of glucose homeostasis.

AMPK is a serine/threonine protein kinase that acts as a sensor of cellular energy homeostasis. It is expressed as a heterotrimer consisting of one catalytic $\alpha$-subunit and 2 regulatory subunits ( $\beta$ and $\gamma$ ) (Stapleton et al. 1997). The $\alpha$-subunit of AMPK is encoded either by the PRKAA1 or PRKAA2 gene, whereas the $\beta$ - and $\gamma$-subunits are encoded by the PRKAB1 or PRKAB2 and the PRKAG1, PRKAG2 or PRKAG3 genes, respectively, yielding 12 possible heterotrimeric complexes, which provide a molecular basis for the multiple roles of the highly conserved AMPK signaling system in nutrient regulation and utilization in distinct mammalian cells (Stapleton et al. 1997, Gao et al. 1996). The different complexes of AMPK confer tissue specificity. Isoform-selective activators or inhibitors of AMPK may thus provide new therapeutic tools for the treatment of type 2 diabetes mellitus. Intestinal AMPK also fulfills key functions in metabolic processes. The prevailing catalytic subunit of AMPK complex in small intestine is $\alpha 1$ and its preferential associated regulatory partners are $\beta 2$ and $\gamma 1$ (Harmel et al. 2014). Because each isoform varies from its sibling forms, the complement of isoforms present in a complex can influence the role and response of AMPK within the cell. In muscle, $\mathrm{AMPK} \alpha 2$ is the predominant subunit representing twothirds of the total $\alpha$ mRNA (Zong et al. 2002). Exercise increases nuclear translocation of AMPK 22 (Goodyear \& Kahn 1998, Birk \& Wojtaszewski 2006), while in AMPK $\alpha 2$ by overexpressing its domain-negative mutant decreased glucose uptake in skeletal muscle in response to contraction (Mu et al. 2001, Steinberg et al. 2006). In pancreatic $\beta$-cells, the $\alpha 2$-subunit displays substantial nuclear localization and is thus implicated in the control of gene expression. On the other hand, $\alpha 1$-containing complex whose total activity exceeds that of $\alpha 2$-containing complex by 5 - to 10 -fold is mainly cytosolic and is proposed to regulate plasma membrane ion channels and secretion of insulin (da Silva Xavier et al. 2000, 2003). Previous studies have showed that AICAR, an AMPK activator, increases GLP1 secretion in rodents but not in fetal rat intestinal cells, murine GLUTag or human NCI-H716 L cells (Maida et al. 2011, Mulherin et al. 2011). Our findings suggest that AMPKo1 alters both the transcription and secretion of GLP1 in STC-1 cells. AMPK 1 1-containing complex suppresses proglucagon mRNA and protein and the secretion of GLP1 by overexpressing this subunit. Inhibition of AMPK $\alpha 1$ signaling by AMPK $\alpha 1$ siRNA or a dominant negative form of $A M P K \alpha 1$ increases the expression and secretion of GLP1. Our experiments thus provide evidence that AMPK $\alpha 1$ modulates GLP1 synthesis and release in the STC-1 cell line, a remarkable intestinal L cell model. These findings are consistent with our previous observations demonstrating that mTOR activity stimulates GLP1 production in L-like cells (Xu et al. 2015a,b). AMPK has been well characterized to suppress mTOR signaling through tuberous sclerosis complex 1 and 2 (TSC1/2) (Inoki et al. 2006). AMPK may thus inhibit GLP1 through mTOR in L cells.

As an insulinotropic and glucagonostatic hormone that inhibits appetite and reduces body weight, GLP1 is a promising therapy for type 2 diabetes (Baggio \& Drucker 2007). GLP1 receptor agonists (Buse et al. 2004)

Published by Bioscientifica Ltd. 
and dipeptidyl peptidase-4 inhibitors (Aschner et al. 2006) have been widely used as treatment targeting $\beta$-cell dysfunction in patients with type 2 diabetes. However, the use of these drugs may be associated with certain adverse effects on pancreatic and thyroid tissues. Both animal studies and analyses of drug databases have indicated an association of GLP1 receptor agonists with pancreatitis, pancreatic cancer and thyroid cancer (Bjerre et al. 2010, Parks \& Rosebraugh 2010). Our study provides an alternative strategy for manipulation of GLP1 by altering AMPK activity in colon mucosa. If the relationship of AMPK signaling with GLP1 production exists in normal and diabetic humans, it might be feasible to target AMPK in colon mucosa for the therapy of type 2 diabetes. In summary, the data presented here demonstrate that AMPK $\alpha 1$ may link energy supply with the production of GLP1 in L-like cells.

\section{Supplementary data}

This is linked to the online version of the paper at http://dx.doi.org/10.1530/ JME-16-0099.

\section{Declaration of interest}

The authors declare that there is no conflict of interest that could be perceived as prejudicing the impartiality of the research reported.

\section{Funding}

This work was supported by grants from the National Natural Science Foundation of China (31401001, 81330010, 81390354); the Science and Technology Planning Project of Guangdong Province, China (2014A020212210); the Guangdong Medical Science Research Foundation (A2014375) and the Scientific Research Foundation for the Returned Overseas Chinese Scholars, State Education Ministry (20141685), and special grants from the Guangzhou Pearl River Young Talents of Science and Technology (201610010079), the Fundamental Research Funds for the Central Universities (21615329) and the Guangzhou Science and Technology Project (2014Y2-00097).

\section{Author contribution statement}

Xu G and Zhang W designed the research; Jiang S, Zhai H, Li D, Huang J, Zhang $\mathrm{H}$ and Li Z performed the research; Xu G and Jiang $\mathrm{S}$ analyzed the data; Xu G and Zhang $\mathrm{W}$ wrote and edited the paper. All authors contributed to the discussion and revised the article and all of them approved the final versions of the manuscript. Xu G and Zhang $\mathrm{W}$ are responsible for the integrity of the work as a whole.

\section{Acknowledgements}

The authors thank Dr Kunliang Guan (University of California San Diego, San Diego, CA) for providing wild-type AMPK $\alpha 1$ (WT), constitutively active form of $A M P K \alpha 1(A F)$, dominant negative form of AMPK $\alpha 1$ (DN) plasmids, wild-type AMPK $\alpha 2$ (WT), constitutively active form of AMPK $\alpha 2$ (AF) and dominant negative form of AMPK $\alpha 2$ (DN) plasmids.

\section{References}

Aschner P, Kipnes MS, Lunceford JK, Sanchez M, Mickel C \& Williams-Herman DE 2006 Effect of the dipeptidyl peptidase-4 inhibitor sitagliptin as monotherapy on glycemic control in patients with type 2 diabetes. Diabetes Care 29 2632-2637. (doi:10.2337/dc06-0703)

Baggio LL \& Drucker DJ 2007 Biology of incretins: GLP-1 and GIP. Gastroenterology 132 2131-2157. (doi:10.1053/j.gastro.2007.03.054)

Birk JB \& Wojtaszewski JF 2006 Predominant $\alpha 2 / \beta 2 / \gamma 3$ AMPK activation during exercise in human skeletal muscle. Journal of Physiology $\mathbf{5 7 7}$ 1021-1032. (doi:10.1113/jphysiol.2006.120972)

Bjerre KL, Madsen LW, Andersen S, Almholt K, de Boer AS, Drucker DJ, Gotfredsen C, Egerod FL, Hegelund AC, Jacobsen H, et al. 2010 Glucagon-like Peptide-1 receptor agonists activate rodent thyroid C-cells causing calcitonin release and C-cell proliferation. Endocrinology 151 1473-1486. (doi:10.1210/en.2009-1272)

Buse JB, Henry RR, Han J, Kim DD, Fineman MS \& Baron AD 2004 Effects of exenatide (exendin-4) on glycemic control over 30 weeks in sulfonylurea-treated patients with type 2 diabetes. Diabetes Care 27 2628-2635. (doi:10.2337/diacare.27.11.2628)

Corradetti MN, Inoki K, Bardeesy N, DePinho RA \& Guan KL 2004 Regulation of the TSC pathway by LKB1: evidence of a molecular link between tuberous sclerosis complex and Peutz-Jeghers syndrome. Genes \& Development 18 1533-1538.

Da Silva Xavier G, Leclerc I, Salt IP, Doiron B, Hardie DG, Kahn A \& Rutter GA 2000 Role of AMP-activated protein kinase in the regulation by glucose of islet beta cell gene expression. PNAS $\mathbf{9 7}$ 4023-4028. (doi:10.1073/pnas.97.8.4023)

Da Silva Xavier G, Leclerc I, Varadi A, Tsuboi T, Moule SK \& Rutter GA 2003 Role for AMP-activated protein kinase in glucose-stimulated insulin secretion and preproinsulin gene expression. Biochemical Journal 371 761-774. (doi:10.1042/bj20021812)

Deacon CF, Nauck MA, Toft-Nielsen M, Pridal L, Willms B \& Holst JJ 1995 Both subcutaneously and intravenously administered glucagonlike peptide 1 are rapidly degraded from the NH2-terminus in type II diabetic patients and in healthy subjects. Diabetes 44 1126-1131. (doi:10.2337/diab.44.9.1126)

De Morentin P, González CR, Saha AK, Martins L, Diéguez C, Vidal-Puig A, Tena-Sempere M \& López M 2011 Hypothalamic AMP-activated protein kinase as a mediator of whole body energy balance. Reviews in Endocrine and Metabolic Disorders 12 127-140. (doi:10.1007/s11154-011-9165-5)

Drucker DJ \& Asa S 1988 Glucagon gene expression in vertebrate brain Journal of Biological Chemistry 263 13475-13478.

Elahi D, McAloon-Dyke M, Fukagawa NK, Meneilly GS, Sclater AL, Minaker KL, Habener JF \& Andersen DK 1994 The insulinotropic actions of glucose-dependent insulinotropic polypeptide (GIP) and glucagon-like peptide-1 (7-37) in normal and diabetic subjects. Regulatory Peptides 51 63-74. (doi:10.1016/0167-0115(94)90136-8)

Friedrichsen M, Mortensen B, Pehmøller C, Birk JB \& Wojtaszewski JF 2013 Exercise-induced AMPK activity in skeletal muscle: role in glucose uptake and insulin sensitivity. Molecular and Cellular Endocrinology 366 204-214. (doi:10.1016/j.mce.2012.06.013)

Gao G, Fernandez CS, Stapleton D, Auster AS, Widmer J, Dyck JR, Kemp BE \& Witters LA 1996 Non-catalytic beta- and gamma-subunit isoforms of the 5'-AMP-activated protein kinase. Journal of Biological Chemistry 271 8675-8681. (doi:10.1074/jbc.271.15.8675)

Goodyear LJ \& Kahn BB 1998 Exercise, glucose transport, and insulin sensitivity. Annual Review of Medicine 49 235-261. (doi:10.1146/ annurev.med.49.1.235)

Hansen L, Deacon CF, Orskov C \& Holst JJ 1999 Glucagon-like peptide-1-(7-36)amide is transformed to glucagon-like peptide-1-(9-36)amide by dipeptidyl peptidase IV in the capillaries supplying the L cells of the porcine intestine. Endocrinology $\mathbf{1 4 0}$ 5356-5363. (doi:10.1210/endo.140.11.7143) 
Hardie DG, Salt IP, Hawley SA \& Davies SP 1999 AMP-activated protein kinase: an ultrasensitive system for monitoring cellular energy charge. Biochemical Journal 338 717-722. (doi:10.1042/bj3380717)

Harmel E, Grenier E, Bendjoudi Ouadda A, El Chebly M, Ziv E, Beaulieu JF, Sané A, Spahis S, Laville M \& Levy E 2014 AMPK in the small intestine in normal and pathophysiological conditions. Endocrinology 155 873-888. (doi:10.1210/en.2013-1750)

Hasenour CM, Berglund ED \& Wasserman DH 2013 Emerging role of AMP-activated protein kinase in endocrine control of metabolism in the liver. Molecular and Cellular Endocrinology 366 152-162. (doi:10.1016/j.mce.2012.06.018)

Herrmann C, Göke R, Richter G, Fehmann HC, Arnold R \& Göke B 1995 Glucagon-like peptide-1 and glucose-dependent insulin-releasing polypeptide plasma levels in response to nutrients. Digestion $\mathbf{5 6}$ 117-126. (doi:10.1159/000201231)

Inoki K, Ouyang $\mathrm{H}$, Zhu T, Lindvall C, Wang $\mathrm{Y}$, Zhang $\mathrm{X}$, Yang $\mathrm{Q}$ Bennett C, Harada Y, Stankunas K, et al. 2006 TSC2 integrates Wnt and energy signals via a coordinated phosphorylation by AMPK and GSK3 to regulate cell growth. Cell 126 955-968. (doi:10.1016/j. cell.2006.06.055)

Jiang S, Hong X \& Xu G 2015 Regulation of food intake by fuel sensors. Diabetes Research and Metabolism 1001.

Kim MS \& Lee KU 2005 Role of hypothalamic 5'-AMP-activated protein kinase in the regulation of food intake and energy homeostasis. Journal of Molecular Medicine 83 514-520. (doi:10.1007/s00109-0050659-z)

Maida A, Lamont BJ, Cao X \& Drucker DJ 2011 Metformin regulates the incretin receptor axis via a pathway dependent on peroxisome proliferator-activated receptor- $\alpha$ in mice. Diabetologia 54 339-349. (doi:10.1007/s00125-010-1937-z)

Mansour A, Hosseini S, Larijani B, Pajouhi M \& Mohajeri-Tehrani MR 2013 Nutrients related to GLP1 secretory responses. Nutrition 29 813-820. (doi:10.1016/j.nut.2012.11.015)

Minokoshi Y, Alquier T, Furukawa N, Kim YB, Lee A, Xue B, Mu J, Foufelle F, Ferré P, Birnbaum MJ, et al. 2004 AMP-kinase regulates food intake by responding to hormonal and nutrient signals in the hypothalamus. Nature 428 569-574. (doi:10.1038/nature02440)

Mojsov S, Heinrich G, Wilson IB, Ravazzola M, Orci L \& Habener JF 1986 Preproglucagon gene expression in pancreas and intestine diversifies at the level of post-translational processing. Journal of Biological Chemistry 261 11880-11889.
Mu J, Brozinick JT Jr, Valladares O, Bucan M \& Birnbaum MJ 2001 A role for AMP-activated protein kinase in contraction- and hypoxiaregulated glucose transport in skeletal muscle. Molecular Cell 7 1085-1094. (doi:10.1016/S1097-2765(01)00251-9)

Mulherin AJ, Oh AH, Kim H, Grieco A, Lauffer LM \& Brubaker PL 2011 Mechanisms underlying metformin-induced secretion of glucagon-like peptide-1 from the intestinal L cell. Endocrinology 152 4610-4619. (doi:10.1210/en.2011-1485)

Orskov C, Wettergren A \& Holst JJ 1993 Biological effects and metabolic rates of glucagonlike peptide-1 7-36 amide and glucagonlike peptide-1 7-37 in healthy subjects are indistinguishable. Diabetes 42 658-661. (doi:10.2337/diab.42.5.658)

Parks M \& Rosebraugh C 2010 Weighing risks and benefits of liraglutide the FDA's review of a new antidiabetic therapy. New England Journal of Medicine 362 774-777. (doi:10.1056/NEJMp1001578)

Stapleton D, Woollatt E, Mitchelhill KI, Nicholl JK, Fernandez CS, Michell BJ, Witters LA, Power DA, Sutherland GR \& Kemp BE 1997 AMP-activated protein kinase isoenzyme family: subunit structure and chromosomal location. FEBS Letters 409 452-456. (doi:10.1016/ S0014-5793(97)00569-3)

Stark R, Ashley SE \& Andrews ZB 2013 AMPK and the neuroendocrine regulation of appetite and energy expenditure. Molecular and Cellular Endocrinology 366 215-223. (doi:10.1016/j.mce.2012.06.012)

Steinberg GR, Watt MJ, McGee SL, Chan S, Hargreaves M, Febbraio MA, Stapleton D \& Kemp BE 2006 Reduced glycogen availability is associated with increased AMPKalpha2 activity, nuclear AMPKalpha2 protein abundance, and GLUT4 mRNA expression in contracting human skeletal muscle. Applied Physiology, Nutrition, and Metabolism 31 302-312. (doi:10.1139/h06-003)

Xu G, Li Z, Ding L, Tang H, Guo S, Liang H, Wang H \& Zhang W $2015 a$ Intestinal mTOR regulates GLP-1 production in mouse L cells. Diabetologia 58 1887-1897. (doi:10.1007/s00125-0153632-6)

Xu G, Hong X, Tang H, Jiang S, Liu F, Shen Z, Li Z \& Zhang W 2015b Ghrelin regulates GLP-1 production through mTOR signaling in L cells. Molecular and Cellular Endocrinology 416 9-18. (doi:10.1016/j. mce.2015.08.016)

Zong H, Ren JM, Young LH, Pypaert M, Mu J, Birnbaum MJ \& Shulman GI 2002 AMP kinase is required for mitochondrial biogenesis in skeletal muscle in response to chronic energy deprivation. PNAS 99 15983-15987. (doi:10.1073/pnas.252625599)

Received in final form 17 July 2016

Accepted 4 August 2016

Accepted Preprint published online 4 August 2016
() 2016 Society for Endocrinology Printed in Great Britain 